\title{
CHANGING EMPERORSHIP: SETTING THE SCENE
}

For any scholar who is examining power and status relations in Roman imperial times, the position of the emperor is a logical starting point. Although it seems obvious that the emperor's office held the greatest power within the Empire, it cannot be accepted unquestioningly that emperors kept exercising the highest power in the same way, given that the Roman world changed so much between AD 193 and 284. However, while the position of individual emperors was hardly ever unchallenged in the third century, especially from 235 to 284 , the emperor as such remained the focal point of the Empire. Under Diocletian, emperorship underwent several changes. Most apparently, four men governed, instead of one under the Tetrarchy, and the emperors presented themselves as domini rather than principes. ${ }^{1}$ There had been a major shift away from emperorship as it had functioned in the first and second centuries AD. These changes made by Diocletian of course resulted from a process of transition that had started long before.

The development of emperorship-or elements of it-in the third century has received abundant attention in recent studies. ${ }^{2}$ As noted above, a discussion of the power and status of the third-century emperor, focusing particularly on developments that could potentially have undermined his authority, is indispensable for my study. Yet, as much of this has already been dealt with in detail elsewhere, this chapter will be relatively brief and will serve as an introduction to the history and problems of the period AD 193 to 284. It will also contain a summary of recent theories on the transformation of emperorship, and introduce the other parts of this book.

${ }^{1}$ See Aurelius Victor, Liber de Caesaribus 39, 4, on Diocletian being called dominus. For recent studies on emperorship under the Tetrarchy, see, for instance, Rémy (1998); Rees (2004); Demandt-Goltz (2004); Boschung-Eck (2006).

2 See, for example, Johne (2008), and generic overviews such as Sommer (2004); Hekster (2008), 56-68. Millar (1992) and Ando (2000) do not focus on the third century only, but are extremely useful to anyone who studies emperorship between 193 and 284 . 


\subsection{Factors Influencing Emperorship between $A D 193$ and 284}

\section{The Changing Background of the Emperor ${ }^{3}$}

As the Principate developed from a Republic in which the nobility gathered in the senate carried out the essential offices, and the princeps combined spheres of power previously held by senatorial magistrates, it was only natural that the emperorship was initially assigned to a senator. ${ }^{4}$ Eventually, however, equites could also ascend the imperial throne. During the first and second centuries AD, the principle of a senatorial princeps was endured, although toward the end of the second century men who had risen from equestrian ranks can be found among the imperial candidates. Both Pertinax and Pescennius Niger were Italic homines novi, who embarked upon an equestrian career, but rose to senatorial rank through adlectio. Pertinax even was of very humble origin: he descended from a freedman. ${ }^{5}$ Septimius Severus was the son of an eques, yet he had immediately initiated a senatorial cursus honorum. The Augusti of the first and second centuries AD were all either from the Italic peninsula, or originating from the Latin-speaking aristocracy of the Western provinces. ${ }^{6}$ Like Pertinax and Pescennius Niger, Didius Iulianus was also born in Italy. His

3 This section is largely based on the information gathered by Kienast (1996), 152263; Johne (2008); and several biographies on individual emperors or specific periods in the third century, such as De Blois (1976); Dietz (1980); Birley (1988); Körner (2002); Kreucher (2003).

4 The literature on the transition of Republic to Principate is immense. On the emperor as a senator, see, for example, Wallace-Hadrill (1996); on the senate in the early Empire, see Talbert (1984); id. (1996).

5 Pertinax: adlectus inter tribunicios (or aedilicios?), circa 170/171. Niger: adlectus inter praetorios, $180 / 183$ ?. Avidius Cassius, the son of an equestrian orator who managed to enter the senate under Marcus Aurelius and who seized power in the East in 175, may be added to this category of imperial candidates with equestrian roots. See Kienast (1996), 142-143; 152-153; 159-160. Cf. Vespasianus, who also became emperor with a fairly humble background. According to Suetonius, Divi Vesp. 12, 1-2, his father was of equestrian rank.

6 The Iulio-Claudian emperors stem from ancient patrician gentes bound to Rome; the Flavians belonged to the Italic municipal aristocracy; Traianus' family came from Italica, in Hispania Baetica, which was also the hometown of Hadrianus' family. It remains unclear, however, whether Traianus and Hadrianus were born in Italica. On Traianus compare Kienast (1996), 122, and Eck (2002b), 10; on Hadrianus, see Syme (1964), 142143; Birley (1997), 10; and Canto (2002). Antoninus Pius was from Lanuvium, Italy; Marcus Aurelius and Lucius Verus were born in Rome; and Commodus in Lanuvium. This development coincided with a more general gradual shift of power from the Empire's geographical center: in the second century, men from the East entered the Senate in Rome. See Halfmann (1979). 
father was a member of the aristocracy of Mediolanum (modern Milan), and his mother came from an eminent North African family. Septimius Severus descended from the municipal aristocracy of Lepcis Magna in Africa Proconsularis, and Clodius Albinus, who supported Severus during his first years of reign, was also of noble African birth.

In 217, a new development occurred: Opellius Macrinus, a man of equestrian status, was proclaimed emperor. He was praetorian prefect at the time of his proclamation, and thus belonged to the top of the ordo equester. Macrinus was of African origin, but he was ethnically Moorish and his family belonged not to the African aristocracy, but to the lower strata of the provincial population of Mauretania Caesariensis. Macrinus' family lacked connections with senators in Italy, which Severus' family had held. Only Pertinax had been of similarly humble origin, yet he had risen to senatorial rank by the time he was proclaimed. Soon, however, the Syrian princesses, who were related to the Severan house through Severus' wife Iulia Domna, engineered that Macrinus be deposed and replaced by Elagabalus, claiming that the latter was a son of the former emperor Caracalla. After a reign of about four years, Elagabalus was himself replaced by Severus Alexander, the last emperor from the Severan dynasty. ${ }^{7}$

Whereas Macrinus' proclamation constituted merely an interlude within the senatorial Severan dynasty, the accession of Maximus Thrax in 235 made clear that an eques acting as emperor had been no aberration. Unlike Macrinus, Maximinus had not been praetorian prefect and therefore was not the highest-ranking eques at the time of his acclamation. Maximinus was a professional soldier who had worked his way up to the equestrian position of praefectus tironibus, recruiting and training new soldiers in the Rhine area. In 217, when the imperial throne was initially offered to Oclatinius Adventus, the Empire could already have had his first professional military officer as emperor. Yet Adventus, who was very old and lacked the standard elite education, had acknowledged that he was not suited for the position and declined. ${ }^{8}$ About twenty years later, however, the first emperor with a pre-imperial career as professional military man was a fact. This coincided with another novelty: Maximinus, who was either from Thracia or Moesia Inferior, was the first emperor

${ }^{7}$ On the role the Syrian empresses played in the accession of Elagabalus and Severus Alexander and during their reigns, see Levick (2007), 145-163.

${ }^{8}$ Dio 79, 14, 2; Herodianus 4, 14, 2. On Oclatinius Adventus' career, see also sections 3.3 and 4.1 . 
who originated from the border region in the lower-Danube region, the so-called Illyrian area. Maximinus' reign did not last very long: in 238, the senate recognized senator Gordianus I, proconsul of the province of Africa Proconsularis, as the new emperor, and he appointed his son Gordianus II as his co-ruler. Maximinus did not give in, and mobilized the Numidian legion to defeat the Gordiani. Nevertheless, a second senatorial revolt the same year, followed by mutiny among Maximinus' soldiers as they besieged Aquileia, caused the death of Maximinus and his son, whom he had elevated to the rank of Caesar. ${ }^{9}$

Maximinus was succeeded by Pupienus and Balbinus. The latter was a patrician of ancient nobility, probably from Hispania Baetica. He had been governor of Asia under Septimius Severus and consul iterum with Caracalla in 213. Pupienus was a senatorial vir militaris of Italic origin, perhaps a homo novus, who had worked his way up to the top of the senatorial cursus honorum under the Severi. ${ }^{10}$ Both maintained good relations with the emperors of the Severan dynasty as imperial amici. ${ }^{11}$ The proclamation of two emperors might be seen as an attempt to restore the old republican principle of two consuls governing jointly. Yet, it is more likely that each of the two was supported by a different section of the senate, each wanting its own representative on the throne: the traditional senatorial aristocracy on the one hand, and a relatively new crop of senators on the other hand who had ascended through the senatorial career path through military posts and other positions in the imperial service. ${ }^{12}$ The choice of the senate obviously did not please the praetorian guard. Backed by the urban plebs in Rome, the praetorian cohorts first forced Balbinus and Pupienus to elevate Gordianus III, a descendant of the Gordiani, to the rank of Caesar, and then dethroned the sitting Augusti. The young Gordianus III, who was born in Rome under Severus Alexander, was proclaimed as their successor. From 241, the Empire was ruled de facto by praetorian prefect Timesitheus, a situation which positioned other equestrian men the chance to enhance their power. ${ }^{13}$ When

${ }_{9}^{9}$ On the senatorial revolt in 238, see Dietz (1980); Haegemans (2005).

${ }^{10}$ In the context of this study the phrase vir militaris is used to refer 'to anyone who had some experience of military life or had chanced to make a reputation in warfare'. Cf. Campbell (1975), 11-12. Whether there was a homogeneous group of specialist viri militares with a distinctive career and special promotion, is debated among scholars. On the debate, see Campbell (1975) and Birley (1992), 14-15.

${ }^{11}$ See Crook (1975), 155; 159.

12 Johne (2008), 589-590.

13 On Timesitheus' career, see section 3.1. 
Gordianus died in 244, another praetorian prefect attained the imperial throne: Philippus Arabs, descending from local potentes from Arabia. For the third time in thirty years, the unwritten rule that the emperorship was reserved for a senator was broken. Philippus presumably had a mixed administrative and military career. His brother Priscus, also of equestrian rank, was virtually his co-regent, ruling the eastern part of the Empire. Yet, remarkably, Priscus was never officially elevated to the rank of Caesar or Augustus, nor even granted senatorial status. This underscores the changing role of senators within the socio-political hierarchies, an issue which will regularly recur in this study. ${ }^{14}$

Philippus Arabs was eventually dethroned by Decius in 249. Ironically, the emperor had created the opportunity for Decius to seize power, by sending this senator from Sirmium to the Danubian border region to restore order. The united troops of Pannonia and Moesia assigned to his command proclaimed Decius emperor in Pannonia. It is assumed that in the 23os Decius, as governor of Moesia Inferior and of Germania Inferior successively, had been involved in Severus Alexander's German expedition of 234-235. Under Maximinus Thrax, Decius was appointed governor of Hispania Citerior, and under Philippus he became city prefect of Rome. Like Decius, the next emperor Trebonianus Gallus was a consular senator at the time of his proclamation. He originated from Italy, and was governor in Moesia when he seized power after Decius' death. Aemilius Aemilianus was also a senatorial governor of Moesia Superioris when he was proclaimed emperor by the troops and marched against Gallus in Italy. Gallus had to call back to Italy Valerianus, who then held a special command in the upper-Danube border region to ward off Germanic tribes. On their way to Italy, however, when Valerianus received word that Gallus had been defeated, his troops proclaimed him emperor. By autumn 253, Aemilianus had been killed by his own men, and Valerianus was recognized as the new emperor. He made his son Gallienus his co-ruler, elevating him to the rank of Augustus. Valerianus and Gallienus were the last emperors in the third century who were definitely part of the traditional senatorial aristocracy: Valerianus was related through marriage to the influential senatorial gens Egnatia from Italy, and was a vir consularis from circa 238 onwards. ${ }^{15} \mathrm{He}$ had apparently held a leading

14 By the reign of Philippus Arabs, elevating a co-emperor had become current practice, see section 1.2.

15 On the Egnatii, see Chapter 2, especially no. 8 in the Excursus. 
position in the senate under Decius. ${ }^{16}$ With the joint reign of Valerianus and Gallienus in the middle of the third century, the traditional emperorship, shaped and carried out by the senatorial aristocracy, came to an end.

In 268, Gallienus became the victim of a conspiracy of his general staff, which consisted mainly of men of Illyrian origin. The emperor was murdered and succeeded by one of these generals, Marcus Aurelius Claudius, presently known as Claudius II Gothicus. According to the author of the Historia Augusta, Claudius was from Dalmatia or Moesia Superior, and most likely he was cavalry commander at the time the plot was carried out. When Claudius died in 270 , he was succeeded by his brother Aurelius Quintillus. Their nomenclature indicates that they probably were new citizens, whose family had gained citizenship in 212 due to the Constitutio Antoniniana. ${ }^{17}$ Quintillus only reigned for a few weeks. In 270, Domitius Aurelianus was proclaimed emperor; he seems to have been cavalry commander (dux equitum) under both Gallienus and Claudius, and was probably involved in the plot against Gallienus as well. He too was born in the Illyrian area and of humble origins. ${ }^{18}$ It is likely that he worked his way up from being an ordinary soldier to becoming a military officer of equestrian rank. Aurelianus reigned for about five years and was succeeded by Claudius Tacitus, who has for a long time been considered a senatorial rather than a soldier emperor. Whether this attribution is correct is highly disputable. By all odds, Tacitus was a senator who had risen from equestrian ranks, and who had been consul before being proclaimed emperor, which distinguished him from his immediate predecessors. According to Zonaras, he was proclaimed emperor by the army, but the author adds that thereupon Tacitus marched to Rome, and only accepted the imperial insignia when the proclamation was sanctioned by the senate. A senatorial renaissance, as claimed by the Historia Augusta, did not occur in the 270s. Yet, Tacitus may have paid more attention to the senators than the average emperor

\footnotetext{
16 Zonaras 12, 20; Johne (2008), 596; Körner (2002), 350-351.

17 See Buraselis (2007) and Hekster (2008), 45-55, for a summary on the debate on the Constitutio Antoniniana and its consequences with further references.

18 According to the Historia Augusta (HA, Vita Aurel. 3, 1), Aurelianus either was from that part of Moesia which was renamed Dacia Ripensis during his reign, or from Sirmium (Pannonia Inferior). On his humble origins, see also HA, Vita Aurel. 3, 1. The statement found in the Epitome de Caesaribus 35, 1, that he was the son of a senator's tenant (colonus) may have been an invention.
} 
in the second half of the third century did. If so, this was probably what earned him his image. ${ }^{19}$

Tacitus' successor was Annius Florianus, praefectus praetorio at the time of his proclamation and allegedly Tacitus' brother. Considering the nomenclature, he can only have been a half-brother on the maternal side. Florianus only ruled for a few months before he was overthrown by Marcus Aurelius Probus. This man resembles Claudius and Aurelianus in that his name leads one to suspect that he was a new citizen, and he is, in fact, said to have been of humble origin and born in Sirmium. A centurion who had worked his way up to a position as tribune is supposed to have been his father. Probus himself was apparently a miles who eventually became a military commander $(d u x)$, probably of equestrian rank, in the East under Tacitus. Not long after Tacitus' death, Probus was proclaimed emperor by troops in the East. Although his reign lasted a relatively long six years or so, he was killed by soldiers in Sirmium, and his praetorian prefect Carus became the new Augustus. Carus was from Gallia Narbonensis, but nothing further is known about his ancestors. After a few months, Carus made his sons Carinus and Numerianus his co-regents. When Numerianus died in November 284, Diocletian seized power.

As has become clear from this brief narrative, a profound change in the background of the Roman emperors can be detected in the period between AD 193 and 284. Whereas the emperors of the first and second centuries had all been senators at the time of their proclamation, by the third century equites could also ascend the imperial throne. At first this happened incidentally, but from 268 onward most emperors were of equestrian rank when they were proclaimed. This was no sudden change: from the end of the second century, senatorial newcomers, men who had risen from equestrian ranks, can be found among the imperial candidates; they can be considered precursors to the third-century equestrian emperors. This process furthermore entailed a transformation in the career-related background of the imperial candidates. The emperors who dominated until the 230 s had mostly undergone either a

19 Zonaras 12, 28; HA, Vita Taciti; Johne (2008), 598-599; cf. 601-603. The distinction between 'soldier emperors' ('Soldatenkaisern') and 'senatorial emperors' ('Senatskaisern') stems from the middle of the 19th century. As by now it has become clear that this matter should be approached with more subtle distinctions, the division is no longer commonly used. For an overview on this matter, see Hekster (2008), 57-61. 
traditional and relatively short senatorial career, if they belonged to the patrician senatorial aristocracy, or else worked their way up to the top of the senatorial cursus honorum through military posts and other positions in the imperial service. In 235, Maximinus Thrax became the first emperor who rose from being a common soldier to a professional military officer and who, from that position, eventually became emperor. From then on, most emperors reached their position through essentially military posts, and from 268 onward most imperial candidates were men who started their career as professional military men, and had risen to the ranks of equestrian military officers. This obviously coincided with another trend from the middle of the third century: the troops operating in the periphery of the Empire played an increasingly decisive role in the proclamation of new emperors. Moreover, the geographic origin of the emperors shifted markedly from the center to the periphery. The emperors of the first and second centuries, and even those ruling the Empire in the first three decades of the third century, all either had Italic roots or combined provincial roots with close ties to senators based in the Italic peninsula. As the first emperor from the Illyrian area, Maximinus Thrax's rule was the harbinger of a growing trend: the majority of the emperors of the 'Central Empire' from the second half of the third century were Illyrians.

\section{Instability Caused by Internal Struggles and External Threats}

Third-century emperorship also adjusted to the unstable situation in the Empire, caused mainly in the border regions by both internal struggles and external threats. This instability brought about short reigns and rapid changes of imperial power. After a period of expansion, the Roman Empire had reached its territorial peak at the beginning of the second century AD. While the emperor Traianus was still conquering new areas, Hadrianus' and his successors' policies aimed at consolidating territory already conquered. ${ }^{20}$ Instead of being aggressors, the Romans became defenders who prevented other people from crossing their borders and invading their lands. The policy worked well for some decades, but Marcus Aurelius was confronted with not only severe incursions of external enemies on both the northern and eastern frontiers, but also a serious internal threat as Avidius Cassius claimed imperial power in Egypt in

\footnotetext{
${ }^{20}$ On imperial frontier policy, see, for instance, Millar (1981); Mattern (1999); Wilkes (2005).
} 
$172 / 173$. The events during his reign foreshadowed the critical situations which would afflict the Empire and its rulers between AD 193 and $284 .^{21}$

Relations with the tribes inhabiting the area north of the frontiers of the Empire, beyond the Rhine and the Danube, had not been continually hostile, yet they had never been stable either. The Romans had combined diplomacy and warfare to deal with these people. Various emperors had allowed groups of tribesmen to settle within the Empire and had recruited some of them into the Roman army. Around the end of the second century, tribes such as the Alamanni and Franks sought food, lands to farm, workers and protection in the Rhine and Danube areas. As their needs increased over the course of the third century, raids across the frontiers grew more frequent and the invasions more severe. The Eastern Empire presented similar problems. Invasions by the Goths, Quadi, Vandals, and Sarmatae pressured the northeastern border regions and the Balkans. From 255 onward, Goths also threatened Asia Minor from overseas. ${ }^{22}$ Incursions like these occurred during the reign of Caracalla, in the $230 s$ under Severus Alexander, and subsequently under Maximinus Thrax, and recurred regularly from the 240 os onward. ${ }^{23}$

${ }^{21}$ On the external and internal problems during the reign of Marcus Aurelius, see Birley (1987), esp. 140-210; 249-255.

${ }^{22}$ For a detailed discussion of the situation beyond the northern frontiers in the third century, see, for example, Piso (2005); Goltz (2008a), id. (2008b). On the Germanic tribes, see further Todd (2005); for the Goths, see, for instance, Wolfram (2001); on the Alamanni in the third century, Drinkwater (2007).

${ }^{23}$ Caracalla fought against the Alamanni along the borders of Germania Superior and Raetia in 213 (HA, Vita Car. 5). Severus Alexander was up against Germanic tribes from 234 onward (Herodianus 6, 7, 5; HA, Vita Sev. Alex. 59). These fights along the limes in Germania Superior and Raetia were continued by Maximinus Thrax and lasted until 236. From 236, Maximinus campaigned against Sarmatae and free Dacians. Philippus Arabs fought against Carpi in the Danube provinces between 245 and 247 (Zosimus 1, 20; Piso (2005), 51-59). Decius campaigned against Goths in the Balkans in 250251. After a stay in the Balkans, Gallienus fought the Franks at Cologne, and then the Iuthungi and Alamanni in Italy in the 250s. At the end of his sole reign, he campaigned against the Goths and Heruli in the Balkans. Claudius Gothicus defeated the Alamanni in Northern-Italy in 268 (Epitome de Caesaribus 34, 2), and the Goths in the Balkans in 269 (Zosimus 1, 45, 1). Aurelianus contended against the Vandals, the Iuthungi and the Sarmatae in Pannonia in 271, and against the Goths in the Balkan area (HA, Vita Aurel. 22, 2); he decided to give up the province of Dacia because of repeated invasions in 272. In 273, Aurelianus fought against the Carpi in the Balkans, on his way back from the East (HA, Vita Aurel. 30, 4). Around 275 substantial parts of Gallia were invaded. After Aurelianus' successor Tacitus campaigned against the Goths in Asia Minor in 276, Probus contended against the Franks and Alamanni in Gallia, against Germanic tribes in the Rhine area in 277-278, against the Burgundians and Vandals in Raetia (Zosimus 1, 68), the Sarmatae in the Illyrian area (HA, Vita Prob. 16, 2), and Isaurians in Asia Minor (HA, 
In the eastern border of the Empire, the Romans had had to deal with the Parthian empire..$^{24}$ Yet by the reign of Severus Alexander the Parthian empire had been weakened by civil war, so that in 226 the Parthians were finally defeated by the Sassanid dynasty and lost their empire to the Persians. The latter took over the Parthians' role as Rome's most feared enemy in the East. The Sassanids, however, were more aggressive and eager to expand their empire westwards into Roman territory. Above all, they wished to conquer the fortified transportation routes along the Euphrates, from Palmyra to Characene, and strongholds in Middle and Northern Mesopotamia, such as Hatra, Nisibis and Edessa. ${ }^{25}$ The first war against the Persians took place during the reign of Severus Alexander. Other major battles were fought between 240 and 272 under the Persian ruler Shapur I, and the Persians won most of these. ${ }^{26}$ In 260 , this even led to one of the most humiliating events in Roman history, when the emperor Valerianus was captured by the Persians. ${ }^{27}$

Vita Prob. 16, 4; Zosimus 1, 69-70). Carus fought against the Sarmatae in the Balkans, and his son Carinus defeated Germanic tribes in 283. See Halfmann (1986), 223-242, and Kienast (1996), 162-263, for further references. Septimius Severus' campaign against the Caledonian and Maeatae tribes in Britannia in 208-211 ended in peace under Caracalla, which lasted for most of the third century. These tribes should thus not be counted among the continuous enemies in the northern border area of the Empire. On the Severan expedition in Britannia, see Birley (2005), 195-203.

${ }^{24}$ Between 193 and 226, several emperors fought against the Parthians. Septimius Severus campaigned against the Parthians in 195 and again in late 197-198 (Dio 75, 1-3 (pp. 194-201); 76, 9.; HA, Vita Sept. Sev. 16, 1-5). Caracalla initiated a war against the Parthians in 216 (Dio 79, $1 \mathrm{ff}$.; Herodianus 4, 11, 2 ff.), which after his death was concluded by Macrinus with a peace treaty in 217 (Dio 79, 26). See Halfmann (1986), 216-231, and Kienast (1996), 156-171, for further references. On relations between Rome and Parthia, see Campbell (1993).

${ }^{25}$ Drexhage (1988).

26 Severus Alexander waged war against the Persians between 231 and 233 (Herodianus 6, 4-6; HA, Vita Sev. Alex. 50); Gordianus III led an expedition against them in 243-244, whose unsuccessful result caused unrest among the Roman soldiers, whereupon they killed the emperor. Peace was bought by Gordianus' successor Philippus Arabs in 244. In 254/255, Valerianus started a campaign against the Persians, who had taken Antiocheia in 253 (SEG 17, 528). The war against the Persians seems to have been continued after Valerianus' death by Ballista and Septimius Odaenathus. Aurelianus was on his way to fight the Persians in the East when he was murdered in 275 (HA, Vita Aurel. 35, 5; Zosimus 1, 62, 1; Zonaras 12, 27). Carus, finally, campaigned against the Persians, before he died in 283 (HA, Vita Car. 8, 1; Zonaras 12, 30). For further references, see Halfmann (1986), 231-242, and Kienast (1996), 177-259. For a more detailed discussion of the situation beyond the eastern frontiers in the third century, see, for instance, JohneHartmann-Gerhardt (2008), 474-580; on the relations between Rome and the Persians, see also Kettenhofen (1982) and Frye (2005).

27 See Festus, Breviarium 23; Thirteenth Sibylline Oracle 155-171 (with commentary 
The increasing pressure on the northern and eastern frontiers caused unrest within the Empire. Distrust and disaffection brought about internal strife: the Romans started to fight among themselves as soldiers in various parts of the Empire each proclaimed their own emperors. The army had always been able to make or break emperors, but this had never happened in such quick succession as it did in the third century, especially from 235 onward. ${ }^{28}$ The situation in 193, when after Pertinax' death three new emperors were proclaimed-Septimius Severus by the troops in Pannonia Superior, Didius Iulianus by the praetorian guard in Rome, and Pescennius Niger by the troops in Syria-foreshadowed what would become the common state of affairs after the death of the last Severan emperor: soldiers proclaimed more than fifty emperors in about fifty years. Some of these emperors survived only a few months before being killed either by rival armies or by the same troops that had initially supported or even proclaimed them. Turmoil and hostility emerged mainly among soldiers in areas which were afflicted by external pressure, and it was the troops in those areas-the Rhine and Danube region, the Balkans, on the Syrian borders-who proclaimed new emperors most frequently. Usurpers arose in those corners of the Empire where the emperor was absent, so that he became merely a somewhat distant concept to subjects and resident army divisions. Thus, as support for a coup lay present there, imperial power was obviously not represented in a decisive and satisfactory way. Dio, for example, reports that two legati legionis stationed in Syria were proclaimed emperor in 219, not long after Elagabalus had left the province for Rome. ${ }^{29}$ The emperor's decision to depart for the capital thus proved dangerous. The areas most frequently afflicted by external pressure and internal strife between emperors and counter-emperors, were obviously most affected by third-century events, either positively, as the presence of troops could stimulate trade, or negatively, as rampaging armies could disrupt social and economic life. ${ }^{30}$

in Potter 1990) for the Roman point of view, and Res Gestae Divi Saporis, 9-11 (with commentary in Frye 1984) for the Persian viewpoint.

${ }^{28}$ On the significance of military support for emperors until 235, see Campbell (1984), esp. $365-414$.

${ }_{29}$ Dio 80, 7, 1, on Gellius Maximus, legatus legionis IV Scythicae, proclaimed in Syria Coele, and ... s Verus, legatus legionis III Gallicae, whose full name is unknown and who was proclaimed in Syria Phoenice at about the same time. Both of them were killed shortly after their proclamation.

${ }^{30}$ Cf. De Blois (2007c), 8. Most scholars now acknowledge that regions such as Africa, Syria and Pamphylia prospered in the third century; see, for instance, Borg-Witschel (2001), 61; Duncan-Jones (2004); Mitchell (1993), 238. 
Yet, the internal problems were not confined to clashes between Roman troops. In 260, during the reign of Gallienus, shortly after Valerianus was captured by the Persians, the Empire was in danger of splitting up. Problems seemed ubiquitous, and the Roman emperor was deprived of control of two large areas and the armies stationed in each. In the West, a desperate situation led to the onset of a Gallic counter-empire, as Marcus Cassianus Latianius Postumus, Gallienus' military commander on the Rhine, rebelled against the emperor. Postumus defeated Germanic tribes who had invaded Italy and this made him a local savior. ${ }^{31}$ As a consequence, Postumus took up the title Germanicus Maximus, and was proclaimed emperor by his soldiers, after which he marched upon Cologne, where Gallienus' son Saloninus represented imperial power. ${ }^{32}$ Saloninus was put to death and, probably at the end of the summer of 260, some three months after Valerianus' demise, Postumus established an autonomous Gallic empire (Imperium Galliarum), including the provinces of Gallia, Britannia and Hispania, and initially also Raetia. ${ }^{33} \mathrm{He}$ patterned his territorial organization after the Roman Empire, but unlike other usurpers Postumus refused to march on Rome. Obviously, the situation would not have been acceptable for Gallienus, but he did not manage to solve the problem: the Gallic empire continued to exist after Postumus' death in 269, and lasted until the summer of 274.

The East experienced a similar situation. Valerianus' capture left the eastern provinces of the Roman Empire unprotected. Septimius Odaenathus, a nobleman from the rich Syrian caravan city of Palmyra, gathered an army and fought off the Persians. Not only did Odaenathus help Gallienus fight Shapur and recover Mesopotamia, but he also killed the usurper Quietus. Odaenathus' position after his victory is heavily disputed; but it seems that, although he was de facto ruling the East, his continued allegiance to Rome kept him from becoming a usurper such as

31 AE 1993, 1231 (11 September 260, Augsburg, Raetia), a dedication to Victoria for her aid in destroying the Semnoni and Iuthungi. The inscription was erected by the otherwise unknown Marcus Simplicinius Genialis. On the inscription and its significance, see Potter (2004), 256-257; cf. Jehne (1996).

32 Zosimus 1, 38, 2; Zonaras 12, 24, 10-12. Allegedly, Saloninus and his tutor Silvanus had claimed for themselves the booty of a battle which Postumus had distributed amongst his soldiers. See Bleckmann (1992), 242-248.

33 On the Gallic empire, see König (1981); Drinkwater (1987). Emperors and officials of the Gallic empire are not included in my analysis of administration and social hierarchies, as the evidence on the political elite of that area and their careers is too limited for the purpose of this study. Cf. Burnand (2005), vol. 2, 567-611, on men from Gallia in the second half of the third century. 
Postumus. ${ }^{34}$ Since there is no evidence for secession in those years, Gallienus could still claim to be emperor of Syria and its wider surroundings in the 260s, so there was no reason for him to attempt to recover the area. The situation changed, however, when Odaenathus was murdered in $267 / 268$, and was succeeded by his wife Zenobia and their son Vaballathus. Palmyra seems to have changed course, and, as Palmyrene influence spread in the East, it became unclear whether the rulers of Palmyra still accepted Roman sovereignty. In 272, the emperor Aurelianus organized a campaign against the 'Palmyrene empire' to restore order in the East. ${ }^{35}$ The solution which had temporarily stabilized the East had developed into a situation in which the center had clearly lost control. After defeating Zenobia and Vaballathus, Aurelianus decided to solve the Western usurpation as well: in 274 , the emperor defeated Tetricus, the last ruler of the Gallic empire. Local military superiority had been the power base of both Odaenathus in the East and Postumus in the West. The fact that both of them settled for local authority enabled both the Gallic empire and the autonomy of Palmyra to last for more than ten years, as the Roman imperial center did not consider them an immediate threat. Yet the emergence of these breakaway 'states' at the height of the third-century crises seriously challenged the unity of the Empire, which in a way undermined the authority of the Roman emperors at the center in the 260 s, who were unable to solve the situation. Besides, this development increased the influence of the Danube forces and their leaders within the 'Central Empire'.

Under these unstable circumstances, Roman emperors continued to express dynastic expectations. Almost all the emperors who had the chance promoted a successor by exalting their son or sons to the rank of Caesar or Augustus. ${ }^{36}$ Dynastic claims were often enforced by appointing

${ }^{34}$ On Odaenathus' career, see section 4.2.

35 On Palmyra's change of course, see Millar (1993), 170-173; on the 'Palmyrene empire', see Hartmann (2001); Hartmann (2008c). Rulers and officials of the 'Palmyrene empire' are not included in my analysis, as its administrative structures are poorly understood and probably more comparable to an Oriental kingdom than to the 'Central Empire'.

${ }^{36}$ By exalting sons to the rank of Caesar or referring to them as princeps iuventutis, emperors expressed dynastic expectations. Yet, they clearly did not consider the time ripe to actually designate them as their successors by making them Augusti. The motive for such restraint must have varied from case to case. According to HA, Vita Pert. 6, 9, Pertinax prevented his son from being called Caesar, but some inscriptions refer to his son as princeps iuventutis (CIL 3.14149, $35=I L S$ 5842; CIL 3.14149, $38=I L S 5845$ (both Arabia)). 
their sons as fellow consuls. Frequently, emperors chose a symbolic moment in their reign to make such dynastic statements, so that the appointments coincided with, for instance, the defeat of a rival or the celebration of a victory over external enemies. ${ }^{37}$ Yet, only one successful dynasty (the Severan) existed between 193 and 284. From the death of Severus Alexander onward, ruling emperors no longer managed to establish a dynasty which would last for any considerable length of time. The Gordiani, although there were three of them, did not found an enduring dynasty, as the first two only ruled a limited territory for about three weeks in 238, and Gordianus III, who was very young when he was made Augustus, only reigned for about six years, during which time the imperial power lay de facto in the hands of his praetorian prefect and fatherin-law Timesitheus. The emperor Valerianus made obvious attempts to establish a dynasty, as he made his son Gallienus his co-ruler. Valerianus Iunior, probably the son of Gallienus, was elevated to the rank of Caesar during the joint reign of Valerianus and Gallienus. He died, however, in $257 / 258$, even before the senior emperor Valerianus was captured. ${ }^{38}$ By the time Gallienus became sole ruler, the authority of the dynasty must have suffered terribly by the humiliation of Valerianus' capture by the Persians. Saloninus, Gallienus' younger son, who had been made Caesar in 258, and represented the imperial family in Cologne in 260 , became the victim of Postumus' claim for power in the Gallic area. If Gallienus still had dynastic hopes at that point, they probably ended with the death of Saloninus. ${ }^{39}$ Valerianus' dynasty had not survived for more than two

37 Some examples: Caracalla replaced Clodius Albinus as Caesar when Albinus was proclaimed Augustus by the troops in Britannia. Not long after Albinus was defeated, Caracalla was exalted to the rank of Augustus and Geta became Caesar. Geta became Augustus when the Severi were staying in Britannia, during which he had to exercise jurisdiction and administer affairs of the Empire, while Severus and Caracalla were fighting battles. See Herodianus 3, 14, 9; Birley (1988). Diadumenianus became Caesar not long after Macrinus had become Augustus, and he was exalted to the rank of Augustus when the troops in Emesa had abandoned his father. See Dio 79, 17, 1; 19, 1; 34, 2; 37, 6; Herodianus 5, 4, 12; HA, Vita Diadum. 1, 1-5. Iulius Philippus became Caesar when Philippus arrived in Rome after his acclamation and was exalted to the rank of Augustus when his father had returned to Rome after his triumph over the Carpi and Germans. See Körner (2002); on the dates when these titles were conferred, see Kienast (1996), 162-203, with further references.

38 On Valerianus Iunior, see Kienast (1996), 220-221, with further references.

39 Marinianus, consul ordinarius in 268 , either was a son, a nephew, or a cousin of Gallienus. Yet he was only born in 265 and thus no serious candidate for succession at the end of Gallienus' reign. Nevertheless, Marinianus was killed in 268 on the instigation of the senate, according to Zonaras 12, 26; see Kienast (1996), 222. 
generations either. The lack of dynastic stability which arose from 235 onward obviously weakened the position of the Roman emperor further, as an important base for legitimating imperial power, especially toward the military - which had been relevant from the beginning of the Principate onward-was lost. ${ }^{40}$

\section{Changing Priorities}

Both the emperors' changing backgrounds and the rapid turnover of power sources and players, caused by internal strife and external pressure, altered the demands of the emperor's office in the third century: in short, emperors' priorities changed. The rulers of the first and second centuries AD spent much time handling legal, diplomatic, and civiladministrative matters. ${ }^{41}$ As supreme ruler, the emperor was the ultimate judge and administrator in the Empire, and held the final responsibility for all governmental decisions. It was to him that citizens could appeal as a last resort when injustices could not be remedied locally. ${ }^{42}$ Decisions of the emperor's representatives were liable to appeal, but judgments by the emperor himself were not. The relative accessibility to the emperor from Augustus onward, especially in Rome and Italy, had been one of the advantages of the early Empire. ${ }^{43}$ The emphasis Fronto places on the emperor's ability to practice eloquentia in a letter to Marcus Aurelius is not strange. As Fronto observes many things had to be achieved by words and letters. ${ }^{44}$ Although the emperor obviously had secretaries and

40 On the value attached to dynasties by the military, see Timpe (1962), 88; Lendon (1997), 254. Johne (2008), 612-614, argues for an increasing (formal) importance of the empresses in the third century. His assumption is mainly based on the expansion of the titulature of the Augustae. See also Horster (2007), who stresses an increasing importance of dynastic themes on coins in the third century.

${ }^{41}$ For an elaborate survey of the duties of the emperor and the resultant writings, see Millar (1992), 203-272.

${ }^{42}$ In practice, however, emperors even in the first and second centuries often refrained from interfering at the local level. See Herrmann (1990).

${ }^{43}$ Millar (1992), 465-477, on residents' accessibility to the Emperors.

${ }^{44}$ Fronto, Ad M. Antoninum de eloquentia 2, 7: Considera igitur an in hac secunda ratione officiorum contineatur eloquentia stadium. Nam Caesarum est in senatu quae e re sunt suadere, populum de plerisque negotiis in concione appellare, ius iniustum corrigere, per orbem terrae litteras missitare, reges exterarum gentium compellare, sociorum culpas edictis coercere, bene facta laudare, seditiosos compescere, feroces territare. Omnia ista profecta verbis sunt ac litteris agenda. ('Therefore consider whether in this second category of duties the study of eloquence should be included. For the duties of emperors are: to urge necessary steps in the senate; to address the people on very many matters in public meetings; to correct the injustices of the law; to send letters to all parts of the globe; to 
advisers to assist him in these tasks, his good standing and reputation improved if he was able to write his own speeches and pronouncements. As Millar has shown, the emperor's role in these matters was mostly passive: his pronouncements normally reacted to initiatives from other parties. Cases where the emperor actively sought information from any other source seem rare. ${ }^{45}$

When the Empire was at war, the emperor had yet another important duty: to command the army divisions involved. ${ }^{46}$ Due to the increasing military threats in the period under discussion, the emperor's military function must have become ever more important and time-consuming. In combination with the changing backgrounds of the emperors, most of whom were military men after 268 , emperorship acquired an increasingly military character. Consequently, emperors met more military leaders and officers than civil administrators and senatorial magistrates. However, the rise of these emperors with a military background made the ruler less accessible for inhabitants of the Empire who did not belong to the military: they were not the most obvious points of reference for non-military men, and it was sometimes even difficult for them to trace who was emperor at any given time. Non-military tasks continued to be part of imperial duties in the third century, but it is only logical that the third-century emperors, especially after 249 , prioritized their military responsibilities, and had less time for responding to individuals' or cities' requests. Although it is true that economic problems in various areas of the Empire, and the lack of clarity on the authority at the local level, may have caused an increase in the number of petitions sent to the emperor, there is no evidence that the emperor personally dealt with all of these. ${ }^{47}$

According to Cassius Dio, Septimius Severus spent a considerable part of his mornings holding court:

The following is the manner of life that Severus followed in time of peace. He was sure to be doing something before dawn, and afterwards he would take a walk, telling and hearing of the interests of the Empire. Then he

bring compulsion to bear on kings of foreign nations; to repress by their edicts the faults of the provincials, give praise to good actions, quell the seditious and terrify the fierce ones. All these are assuredly things to be achieved by words and letters.' (transl. Millar (1992), 203).

${ }^{45}$ Millar (1992), 266-267.

${ }^{46}$ Cf. Hekster (2007), 91: 'The Emperor was the military leader par excellence.'

47 On petitions sent to the emperors in the third century, see Hauken (1998); cf. Hekster (2008), 62-63, with further references. 
would hold court, unless there were some great festival. Moreover, he used to do this most excellently; for he allowed the litigants plenty of time and he gave us, his advisers, full liberty to speak. He used to hear cases until noon. ${ }^{48}$

Septimius Severus obviously was accessible to his subjects. The author, however, explicitly states that this routine applied only to peacetime. An inscription of an imperial petition sent to Gordianus III in 238 by petitioner Aurelius Pyrrhus, a praetorian soldier, on behalf of the villagers of Skaptopara attests that in those days people still approached the emperor to solve a problem-abuse by soldiers and officials-, yet the emperor's response makes clear that he did not see the need to deal with the problem himself: he sent the villagers straight back to the governor and chose not to get involved in the matter. ${ }^{49}$ Circa 245, Philippus Arabs was approached by another soldier named Didymus. He presented the emperor with a similar petition: the villagers of Aragua in Asia Minor asked for help, after abuse by soldiers and military officers. That soldiers, and not orators as was (more) common in most of the first and second centuries, delivered the messages, indicates both the changing role of the military and the changing means of communicating between the Empire's inhabitants and the emperor. Philippus Arabs, a former eques who most likely had gained experience in the military before he became emperor, and who was fighting the Carpi when the petition reached him, was approached most easily by a soldier, who knew his way into military camps, and could deliver the message to the emperor promptly: there was no need-and perhaps no time-for a formal declamation. ${ }^{50}$ How the emperor responded to the petition from Aragua is unknown.

${ }^{48}$ Dio 77, 17, 1-2. Cf. Herodianus 3, 10, 2; and Dio 52, 33, 5, where Maecenas advises the emperor Augustus to select equestrian men to assist him in his judicial work, his correspondence, and in handling the decrees of the states and the petitions of private individuals. This may refer to the range of emperors' duties in Dio's time, the late second and early third centuries.

${ }^{49}$ CIL 3.12336 = AE 1995, 1373 (Skaptopara, Thracia). Soldiers, visitors, and even the procurators and governors with their staff confiscated goods and demanded accommodation of the villagers of Skaptopara without payment. Skaptopara with its spa-like water was an attractive place to visit. See Halloff (1994); Hauken (1998), 82; 98; 117; De Blois (2007a), 506.

${ }^{50}$ CIL 3.14191 (Asia). See Hauken (1998), 150-153; Mitchell (1999), 43-44; on the message being delivered by a soldier, see also Hekster (2008), 40-41. Cf. Alston (1995), 86-96, and Whitehorne (2004) on the role of centurions conveying petitions to higher officials at provincial and imperial level. 
For non-military men from the center of the Empire, communication with the emperor was not only hampered by the changing backgrounds and origins of the emperors, but also by the fact that emperors resided in Rome less often, as military crises in the East and the West called for imperial presence elsewhere. Nevertheless, most third-century emperors did spend some time in Rome during their reign, either shortly after their proclamation or for celebrations such as triumphs, imperial marriages, or festivals. ${ }^{51}$ Even in the second half of the third century most of the emperors stayed in Rome between waging their wars, during the winter months. They were at least present in the capital when they took office as consul ordinarius, often in January of the year after their proclamation. ${ }^{52}$ Although Rome retained at least a symbolic importance for third-century emperors, long-term stays in the capital were no longer an option for most of the emperors ruling after 250 , as they spent most time in border regions, or in cities situated along the traditional routes from the West to the East. Aquileia (in northern Italy), hosted several emperors as the starting-point of several important roads which led to the northeast of the Empire. Septimius Severus may have stayed there for a while when he was on his way from Pannonia to Rome to claim the throne in the spring of 193. Maximinus Thrax faced resistance when he wanted to cross Aquileia in 238, and Quintillus resided in the city when he was defeated by his rival Aurelianus. The latter also crossed the city when he returned from Rome to fight the Goths in Pannonia in 272. Aquileia's significance becomes clear from the fact that an imperial palace was constructed there in the fourth century, in which emperors resided frequently. ${ }^{53}$

${ }^{51}$ Some examples: Septimius Severus and Caracalla stayed in Rome in 202 when Caracalla married Plautilla. In 204, Severus celebrated the Ludi Saeculares in the capital; Severus Alexander went to Rome to celebrate his triumph over the Persians in 233; Philippus Arabs came to the capital after he had made peace with the Persians by buying them off in 244, and after defeating the Carpi and Germanic tribes in 247. In 248 he was present in Rome when he celebrated the city's thousandth birthday; Gallienus organized games in Rome in 262, probably in honor of his Decennalia. See Halfmann (1986), 216-242.

52 Trebonianus Gallus, Valerianus, Claudius Gothicus, Aurelianus and Carus went to Rome some time after their accession to the throne, and opened the next year as consul ordinarius. Gallienus returned to Rome at the end of 260 , at the beginning of his sole reign, and was consul ordinarius in 261 as well. Aurelianus spent two winters in Rome (270/271 and 271/272), and even returned there to celebrate his triumph over Palmyra in 273, according to Zosimus 1, 61, 1. After defeating several usurpers, Probus celebrated a triumph in Rome, possibly at the end of 281 . He probably was still there when he started his term as consul ordinarius in 282 as well. See Halfmann (1986), 241.

${ }^{53}$ Halfmann (1986), 216; 233; 239; on Septimius Severus' stay in Aquileia, see also Birley (1988), 99; on Aurelianus' stay, see Zosimus 1, 48, 1. 
Perinthus and Byzantium in Thracia on the other hand, were frequently visited by third-century emperors who were on their way to the Eastern half of the Empire. Septimius Severus probably spent the winter of 193/194 in Perinthus, when he was on his way to Syria to fight the Parthians. Coins suggest that he stayed there again on the return trip to Rome. Coins also attest the presence of Caracalla in Perinthus in 214. He must have passed it en route from the Balkans and Danubian provinces to Asia. ${ }^{54}$ According to Dušanić, Philippus Arabs crossed Perinthus on his way from the Danubian provinces to the East, where he intended to wage war against the usurper Iotapianus, when he learned about the rebellion of Decius in Pannonia and was killed. ${ }^{55}$ Byzantium, meanwhile, sided with Niger and was besieged in 196. Septimius Severus rebuilt the city, which quickly regained its prosperity. Aurelianus crossed Byzantium on his way to Syria, where his first battle against Palmyra took place, and might have spent the winter months there on his way back. He was killed between Perinthus and Byzantium in August/September 275. ${ }^{56}$

Other frequently visited cities included Antiocheia (Syria) and Alexandria (Egypt), which with Byzantium/Constantinople grew out to be the most important cities in the eastern part of the Empire in the fourth century. While Alexandria received visits from the Severan emperors mainly out of curiosity, Antiocheia often provided the base for the thirdcentury emperors' operations when they were fighting the Parthians, Persians or Palmyrenes. ${ }^{57}$ Tyana (Cappadocia), Nicaea (Bithynia) and Nicomedia (Bithynia) were also visited regularly by third-century emperors. The locations of Augusta Treverorum (modern Trier) and Colonia Agrippinensis (modern Cologne) exposed the cities to barbarian attacks, while the political intrigues of resident administrators and generals exposed

${ }^{54}$ See Halfmann (1986), 216-217; 224, with further references.

55 Dušanić (1976); Halfmann (1986), 235. In addition, Numerianus may have been killed in Perinthus by his praefectus praetorio Aper on his way from Asia to Europe. See Halfmann (1986), 242.

${ }^{56}$ HA, Vita Aurel., 35, 5; Zosimus 1, 62, 1: Zonaras 12,27; Halfmann (1986), 239. As is well known, Byzantium was renamed Constantinople in the fourth century and became the capital of the Eastern part of the Empire.

57 Alexandria was visited both by Septimius Severus when he travelled through Egypt in 199/200 and by Caracalla in 215. Severus Alexander had planned to go there, but called it off. Antiocheia hosted Caracalla during his journey in Asia Minor in 215. Macrinus used it as his base of operations against the Parthians, and Severus Alexander and Gordianus III attacked the Persians from Antiocheia. During the reign of Valerianus, Antiocheia was invaded by the Persians and Aurelianus' battles against Palmyra took place in the city. See Halfmann (1986), 218-240. 
them to civil war. Postumus chose them as capitals in the Gallic empire. The cities retained their importance from 284 onward as important centers, accommodating emperors and usurpers, imperial administrators, and bishops. Sirmium in Pannonia Inferior deserves attention as well. When it was conquered by the Romans in the first century BC, it already was a settlement with a long tradition. The city, situated on a strategic military location, became the capital of the province. Traianus and Marcus Aurelius had prepared war expeditions there, and in the third century the city was still relevant as a strategic base for the emperors, but it was also the birthplace of several emperors and the city in which several emperors were proclaimed by their soldiers. ${ }^{58}$ Sirmium also remained important after the third century. ${ }^{59}$

Meanwhile, the dominant role of the city of Rome was gradually disappearing, and a general shift in location of power from the center (Rome) to the periphery (the cities in border regions and along lines of march) can be detected. This affected the relation between the emperor and institutions bound to Rome, such as the senate and the praetorian cohorts.

\subsection{Consequences for the Position of the Emperor}

\section{Imperial Tasks Increasingly Performed by Others}

All these events and developments modified not only the relation of the emperor with the political elite, but also the demands of the emperor's office. An increasing tendency to transfer imperial tasks to representatives emerges in the course of the third century. Obviously, Roman

${ }^{58}$ Several emperors established their winter headquarters in Sirmium, like (probably) Caracalla in 213/214, Maximinus Thrax in 237/238 and perhaps Probus in 276/277 (Cod. Iust. 8, 55, 2) and possibly in $278 / 9$. Probus was killed near Sirmium when he was en route to the East to fight the Persians. His successor Carus was proclaimed emperor there, just as Aurelianus had been, after his predecessor Claudius had died in there. Gallienus probably set up his headquarters in Sirmium in 254/ 6 or 260, since he received an embassy there (according to an inscription found in Larissa in Thessaly, see RobertRobert (1951), 167 no. 124; see Halfmann (1986), 223-242).

59 There are archaeological remains of an imperial palace, it possessed an imperial arms factory, was a fleet station (Notitia Dignitatum (occ.) 9, 18; 32, 50) and the site of an imperial mint. Besides, large numbers of laws were issued there from Diocletian's reign onward. See OCD and DNP s.v. Sirmium. See Johne (2008), 629-631, on the new imperial residences in the late Empire, and Haensch (1997) for a detailed discussion of provincial capitals. 
emperors had always delegated many duties to others, who mediated imperial power by carrying out civil-administrative, legal, financial, or military responsibilities in specific geographical areas. The administration of the Empire at the central level was not yet formalized and there was no constitution, nor a comprehensive or binding description of the emperors' duties. The imperial administration could therefore be tailored to the needs of any ruling emperor. ${ }^{60}$ Yet the system of administration that Augustus had created was never changed drastically before 284: adjustments consisted mainly of (gradual) changes in the range of officials' duties or the creation of new offices if circumstances so demanded. In a recent study on Roman imperial administration, Eich has argued in favor of the development over the course of the third century of what he calls a 'personal bureaucracy'. By this he means a system tied to and dependent on the individual person of the emperors and not on traditional aristocracies, which could extract enough money, goods and services from the provinces of the Empire to pay for the military forces. ${ }^{61}$ Based on the premise that in the third century, especially in the second half, the Roman government needed more money, along with other resources and a more extensive defensive structure to withstand outside attacks, Eich argues that the emperors had to raise more funds and so had to tighten fiscal management in the provinces, which led to a more developed personal bureaucracy. ${ }^{62}$ It is true that Eich's assumption that the circumstances demanded a more coordinated bureaucracy with more and more equestrian civil servants, many of whom were juridically trained bureaucrats, cannot be supported with sound evidence. Nonetheless, this tendency toward a more bureaucratic administrative system would parallel emperors' increasing focus on military matters, which left civil-administrative, financial, and legal matters to others. ${ }^{63}$

Other innovations from the third century indicate that the emperor was increasingly delegating tasks to others. The appointments of private

${ }^{60}$ Cf. Peachin (1996), 88: '. . . any emperor, at any moment, had in principle the power to change the law as he saw fit. Conservatism in this respect may have been the norm; but nothing bound Caesar absolutely'

${ }^{61}$ Eich (2005).

${ }^{62}$ A more developed bureaucracy, as administrators' power could extend into more spheres and as the center deployed additional administrators. Cf. Potter (2004), 261-262.

${ }^{63}$ De Blois (2007b), 516-517, accepts Eich's main hypotheses, but criticizes Eich's decision to disconnect this process of bureaucratization from a kind of militarization, and argues that Eich overemphasizes emperors' reorganizations of the apparatus between 260 and 284 . 
individuals to hear cases and dispense justice in place of the emperors has been examined by Peachin. He credits the establishment of an imperial office of substitute imperial judge (iudex vice Caesaris, iudex vice sacra) to Septimius Severus, during whose reign such judges are first attested, and he further demonstrates that such appointments are attested occasionally throughout the third century. ${ }^{64}$ In his extensive discussion of the emperor's judicial role, Peachin convincingly argues that by the end of the second century AD emperors were overloaded with legal business: for administering justice had become so complicated that many judges and litigants seized the opportunity to appeal to the emperor, if a judge's unfairness (iniquitas) and/or inexperience (imperitia) had become apparent. ${ }^{65}$ Special senatorial deputies constituted a functional response to the looming structural problem of legal insecurity which encouraged both litigants and judges to approach the emperor for incontrovertible resolutions. Peachin thus argues that the Severan emperors did not invent the iudices vice Caesaris merely as a means to ward off work, but to execute governmental services more efficiently. Until the 240s, Rome hosted these iudices vice Caesaris the most frequently, but Philippus Arabs seems to have taken the significant step in allocating such judges to the provinces. According to Peachin, the duties of these iudices in provincial settings were not merely judicial. ${ }^{66}$ Furthermore, Peachin detected an increase in the practice of appointing substitute provincial governors during the Severan period, as will be discussed in Chapter 3. Moreover, the first appearance of deputies acting in place of praetorian prefects and city prefects in Rome can also be dated in the Severan era. The practice of appointing such proxy judges culminated in the creation of a permanent body of officials authorized to act judicially vice Caesaris under the emperor Constantine. ${ }^{67}$ Similarly, expansion of the praetorian prefect's spheres of authority in the course of the third century meant that this official increasingly acted vice Caesaris: in both in

${ }^{64}$ Peachin (1996). Burton (1998) points out that Peachin's argument for Severan creation of senatorial officials acting vice Caesaris remains an argumentum ex silentio.

65 Digesta 49, 1, 1 (Ulpianus). Cf. Digesta 1, 4, 1, in which Ulpianus proclaims that whatever the emperor wanted had the force of law. On the judicial role of the emperor, see Peachin (1996), 10-91.

${ }^{66}$ Peachin (1996), 167-187, in which he discusses some provincial iudices appointed from Philippus' reign onwards, who may have had civil-administrative or financial duties besides their legal tasks, although he admits $(171-172)$ that this idea remains speculative.

${ }^{67}$ On the analogous appearance and increase of substitute governors, praetorian prefects and urban prefects, see Peachin (1996), 154-187, and appendix 4, 229-238; on Constantine's reform, see Peachin (1996), 188-199. 
the military and non-military domains, the praetorian prefects gradually assumed ever more tasks that were formerly assigned to emperors, as will also be argued in Chapter 3 .

In a certain sense, the temporary cessions of territory-as with the Gallic and Palmyrene empires-might be seen as comparable, since they entailed a similar sharing of imperial responsibilities. Surely, the circumstances were different: although the central government did not cede territory as a matter of active policy, the assumption by others of certain tasks and the responsibility over some areas relieved the emperors and enabled them to focus on nearer and more urgent matters. Again, it should be stressed that the Roman emperors did not give those areas up of their own free will, and the secession particularly of Gallia and Palmyra announced the collapse of individual emperorship, at least temporarily. That the Empire, with all its problems, had grown to such proportions that it was no longer possible for one man to rule it, was recognized as early as the second half of the second century AD, when Marcus Aurelius and Lucius Verus became co-rulers in the 16os, the former focusing on the West, the latter on the East. Similar attempts at dividing the Empire into an Eastern and a Western part were made in the third century, as Valerianus tried to overcome the accumulation of problems by making Gallienus co-ruler. While Valerianus was dealing with situations of crises in the East, Gallienus took care of the problems in the Western border areas. About ten years before their reign, Philippus Arabs recognized the problem as well, and tried to solve it by giving his brother Priscus supreme authority in the East as corrector Orientis. Yet, as stressed before, Philippus' solution was of different nature, as Priscus was not elevated to the rank of Augustus or even Caesar, and thus did not formally share imperial power. In 282, Carus also considered it necessary to secure imperial presence in both the East and the West. He left his son Carinus behind in the Western part of the Empire, and brought along his son Numerianus to the East to fight against the Persians. The official division of the Empire into Eastern and Western parts under Diocletian was thus not a completely unexpected nor unprecedented step.

\section{Changing Relations between Emperors and the Military}

The events and developments defined above influenced relations between emperors and their subjects. Most significant for the purpose of this study is the transformation of the interrelations between emperors and the various groups involved in central imperial administration. Obviously, 
the increasing military threats affected relations between emperors and the military: it made the emperor more dependent on his troops than ever before. When emperors resided in Rome, in times of relative peace, they were most accessible to those army divisions that were stationed there. That is why in the second and early third century AD, the cohortes urbanae, and especially the cohortes praetoriae, were so often involved in political affairs. ${ }^{68}$ These cohorts held both access to the imperial family and the power to elect emperors. But because emperors visited Rome less frequently in the third century, they were not only surrounded by those divisions of the praetorian guard and of legio II Parthica, which accompanied them, but also by troops in the border regions and the mobile detachments that were increasingly mobilized in the third century. Consequently, high-ranking military officers commanding those troops in the periphery played an ever increasing role in the imperial entourage, while correspondingly the influence of the praetorian cohorts decreased, especially from the 240 s onwards. ${ }^{69}$ Again, a shift of power from center to periphery can be detected. This development coincided with a changing composition of the corps of high-ranking military officers: senators' role as military commanders declined, whereas professional military men who had worked their way up to equestrian ranks were rising, as will be discussed in more detail in Chapter 3 .

When from the 26os onward high-ranking military officers of the border troops and mobile detachments kept being proclaimed emperor, the distinction between emperors and their corps of generals became less sharp. The case studies in Chapter 4 will further demonstrate how this affected relations between the emperors and their high-ranking officers.

\section{Changing Relations between Emperors and the Senate}

Evidently, relations between emperors and senators were influenced by third-century developments as well. The rise of the new military aristocracy in the periphery, in which equestrians rather than senators played a dominant role, combined with the emperors' increasing dependency on the military, and the fact that emperors were eventually more closely allied to the military aristocracy than to the traditional senatorial aristocracy, changed the emperors' relations with senators at several levels.

${ }^{68}$ See Busch (2007) on the troops stationed directly in and around Rome.

${ }^{69}$ The latter's dominant role in political matters, and even in imperial proclamations, was assumed by the troops in the periphery. 
When in the course of the third century it became clear that the senate was no longer the obvious institution for supplying new emperors, this situation initially sparked resistance in 238 . By then, the top of the senate consisted of at least two sections: the traditional senatorial aristocracymostly patrician gentes - and a group of homines novi who were not born senators, but who had worked their way up to top senatorial positions. By the end of the reign of Gallienus, the majority of newly chosen emperors were not only no longer of senatorial status, but they had also risen through military commands-from which senators were by then excluded-, they had reached the imperial throne through support of their troops and were dependent on them to maintain their position. ${ }^{70}$ These emperors were more concerned about preserving the support and loyalty of their armies in the provinces and border regions than they were to secure additional senatorial support. So they became less inclined to set off for Rome to make sure their reign was acknowledged by the senate in the capital.

Not only did the absence of the emperors from Rome hinder the communication with the senate: the changed background of the emperors in the second half of the third century also made it increasingly difficult for emperors to communicate with senators on the same level, as emperors were no longer rhetorically skilled noblemen, but militarily trained professionals. Many senators, especially those belonging to the traditional senatorial elite, may have held these emperors, who in their eyes lacked the appropriate paideia, in contempt. Two additional factors diminished the senate's significance to the emperorship's stability: first, emperors no longer needed senatorial acknowledgement to legitimate their imperial power-so that under Carus at the latest the emperor could act without senatorial recognition-, and second, regional usurpers rose who did not aim for legitimacy within the entire Empire but only parts of it. ${ }^{71}$

The role of senators in central administration gradually changed as well, as from the reign of Septimius Severus onwards emperors tended to replace senators with equestrian men in several provinces, especially those which demanded extensive military responsibilities, as will be discussed in Chapter 3. This change has often been described in detail,

${ }^{70}$ On the exclusion of senators from military commands under Gallienus, see Aurelius Victor, Liber de Caesaribus 33, 33-34; 37, 5-6. Some inscriptions, however, problematize the statements in Victor. On this matter, see, for instance, Pflaum (1976); Cosme (2007). On the 'edict' of Gallienus and the scholarly debate on this matter, see also Chapter 3, section 3.1.

${ }^{71}$ Johne (2008), 624-626. 
but scholars often overlook or at least underrate how the traditional senatorial aristocracy was able to maintain and perhaps even extend its prestigious position within areas which were not struck by long-term crises such as Italy, Africa and Asia, as will be demonstrated in Chapter 2.

\subsection{Conclusion}

As this chapter has sought to indicate, the development of emperorship in the third century is a complicated process in which it is problematic to distinguish causality from correlation. Clearly, the events and developments of the third century served to undermine the stability of the emperor's position. Of course, there had always been civil wars, military disasters, rebellions within the provinces, invasions from beyond the frontiers, famines and plagues, ever since the early history of Rome. As has long been recognized, however, in the third century the Romans faced many of these problems simultaneously, some of them even on a larger scale than before, and they proved more difficult to deal with than in previous centuries.

Viewed from the perspective of Dahl's aspects of power, which have been discussed in the Introduction, it is clear that there was a general decrease in both the scope and domain of the power which Roman emperors could exercise. That subjects who turned to the emperor for help were referred back to regional authorities was not typical for the third century. However, combined with delegation to and assumption by others of other tasks which had formerly been reserved for emperors, reassignment to local judicial authorities may indicate a decreasing centrality of the emperor as the figure to whom Romans could turn in their times of need. Even if some of these measures aimed originally to facilitate more efficient government and administration, intention does not change consequences: the scope of power exercised by emperors grew narrower. A low point was reached with the secession of the Gallic empire and Palmyra, when emperors were forced to give up parts of the Empire, thus reducing the domain in which they exercised power. Moreover, the amount of power exercised by the emperors increasingly shrank, as the functional visibility and utility of the emperor, and thus of imperial authority as a whole, decreased. As had been the case from the early Empire onward, military preponderance expressed through control over substantial army divisions and military successes remained emperors' most essential power base. With the failure of dynastic stability after 
the death of Severus Alexander, an important additional base for legitimating their power-which had been relevant from Augustus onwardswas lost for the emperors.

Furthermore, the status profile of emperors changed in the period under discussion: through the end of the second century AD, emperors had had to be educated senators-either born senators belonging to the traditional aristocracy, or senatorial newcomers - with a network of friends and clients in Rome and preferably some military experience. But at the end of the third century AD, most emperors were military men, born in the periphery of the Empire, who had worked their way up to equestrian ranks and were less familiar with senatorial modes of communicating. Status criteria such as birth, education, experience, and lifestyle had therefore changed immensely, and the significance of imperial candidates' ascribed status seems to have been displaced by their achieved status. The emperor's increasing absence from Rome further complicated communication with the senate. These developments led to emperor Maximinus Thrax's clash with members of the senate in 238 . That senatorial consent was no priority for newly acclaimed emperors in the late third century epitomizes the changing relation between emperors and the senate.

In the third century, emperors surrounded themselves ever more with troops from the periphery, and eventually, from the 260 s onward, highranking military officers were continually proclaimed emperors. This development minimized the distinction between emperors and generals, which further complicated emperors' capacity to legitimate powerat least in senatorial eyes. In addition, communication with emperors was made ever more difficult for senators, not only because they were most accessible to military men, but also because it may not always have been easy to trace rulers who were continuously on the warpath. Meanwhile, the seriousness of many of the problems the Roman Empire faced increasingly demanded immediate interference. Consequently, other men with power were sought out by Romans in need and were mobilized to solve problems which would previously have been brought before the emperor. Given the military character of the majority of the problems in the third century, most of the people addressed at the local level were military leaders, who apparently became ever more aware of their growing power and ever more fearsome rivals for the emperors.

In the end, the shift of priority from center to periphery, which can be detected at several levels, seriously disturbed power balances and obviously affected the position of the emperor in the course of the third 
century. The considerable and growing number of usurpers and the secession of certain areas in the second half of the third century showed clearly that imperial authority was ever more challenged. Moreover, emperors' accessibility diminished rapidly, particularly after about 235 . Due to these developments and consequences, the changes Diocletian made from 284 onward were not only understandable, but quite natural and perhaps even unavoidable. 